\title{
Proxy warfare and the future of conflict: take two
}

Article

Accepted Version

Rauta, V. (2020) Proxy warfare and the future of conflict: take two. RUSI Journal, 165 (2). pp. 1-10. ISSN 1744-0378 doi: https://doi.org/10.1080/03071847.2020.1736437 Available at https://centaur.reading.ac.uk/89886/

It is advisable to refer to the publisher's version if you intend to cite from the work. See Guidance on citing.

To link to this article DOI: http://dx.doi.org/10.1080/03071847.2020.1736437

Publisher: Taylor \& Francis

All outputs in CentAUR are protected by Intellectual Property Rights law, including copyright law. Copyright and IPR is retained by the creators or other copyright holders. Terms and conditions for use of this material are defined in the End User Agreement.

\section{www.reading.ac.uk/centaur}

\section{CentAUR}

Central Archive at the University of Reading

Reading's research outputs online 


\title{
Proxy Warfare and the Future of Conflict: Take Two
}

\author{
Vladimir Rauta
}

[abstract]

While proxy wars have been around since time immemorial, the last decade of conflict has seen a rise in their strategic appeal. In the same way that sub-state violence captured the attention of policymakers and academics at the end of the Cold War, proxy wars are now a core feature of the contemporary and future strategic and security environment. Vladimir Rauta argues for a relocation of proxy wars by conceptualising them as strategic bargains waged on more complex grounds than risk avoidance, cost efficiency and deniability. He identifies two types of strategic goals sought through the employment of proxies: coercing and coping with an adversary, whose differences are presented by contrasting the rationale behind the US decision to support Syrian rebels against President Bashar al-Assad with the Iranian strategy of proxy war in Syria.

[end abstract]

In 2016, then British Foreign Minister Boris Johnson came under fire by the Cabinet for disparaging the role of one of the country's closest allies in the Middle East, Saudi Arabia. He claimed that: 
There are politicians who are twisting and abusing religion and different strains of the same religion in order to further their own political objectives. That's one of the biggest political problems in the whole region. And the tragedy for me - and that's why you have these proxy wars being fought the whole time in that area - is that there is not strong enough leadership in the countries themselves.... That's why you've got the Saudis, Iran, everybody, moving in, and puppeteering and playing proxy wars. $^{1}$

Johnson's puppeteering remarks concerned Yemen, a country whose civil war saw direct Saudi and Emirati military intervention, and highly disputed proxy intervention in the form of Iranian support to Houthi rebels. ${ }^{2}$ They also underline how policymakers on both sides of the Atlantic have come to view the complexity of Middle Eastern politics through the lens of proxy wars, while simultaneously publicly condemning and secretly waging them. ${ }^{3}$ The practitioners' emphasis on the value of the notion of 'proxy war' has been mirrored by the nascent literature on proxy war'

\footnotetext{
${ }^{1}$ Patrick Wintour, Rowena Mason and Saeed Kamali Dehghan, 'Johnson Says Saudi Arabia is a "Puppeteer" in Middle East Proxy Wars', The Guardian, 8 December 2016.

2 Joseph L Votel, 'Great Power Competition: The Current and Future Challenges in the Middle East', Statement Before the Senate Armed Services Committee on the Posture of US Central Command, 5 February 2019.

${ }^{3}$ Mark Mazzetti, Adam Goldman and Michael S Schmidt, 'Behind the Sudden Death of a \$1 Billion Secret C.I.A. War in Syria', New York Times, 2 August 2017.

${ }^{4}$ Eli Berman and David A Lake (eds), Proxy Wars: Suppressing Violence Through Local Agents (Ithaca, NY and London: Cornell University Press, 2019); Tyron L Groh, Proxy War: The Least Bad Option (Stanford, CA: Stanford University Press, 2019); Jakob Hauter, 'Delegated Interstate War:
} 
and the expansion of the literature on the links between civil war and the provision of external support to warring factions. ${ }^{5}$ This debate has drawn on the transformation of

Introducing an Addition to Armed Conflict Typologies', Journal of Strategic Security (Vol. 12, No. 4, 2019), pp. 90-103; Vladimir Rauta, 'A Structural-Relational Analysis of Party Dynamics in Proxy Wars', International Relations (Vol. 32, No. 4, 2018), pp. 449-67; Vladimir Rauta and Andrew Mumford, 'Proxy Wars and the Contemporary Security Environment', in Robert Dover, Huw Dylan and Michael S Goodman (eds), The Palgrave Handbook of Security, Risk and Intelligence (London: Palgrave Macmillan, 2017), pp. 99-116; Seyom Brown, 'Purposes and Pitfalls of War by Proxy: A Systemic Analysis', Small Wars and Insurgencies (Vol. 27, No. 3, 2016), pp. 243-57; Andrew Mumford, Proxy Warfare (Cambridge: Polity Press, 2013); Geraint Hughes, My Enemy's Enemy: Proxy Warfare in International Politics (Eastbourne: Sussex Academic Press, 2012).

${ }^{5}$ Noel Anderson, 'Competitive Intervention, Protracted Conflict, and the Global Prevalence of Civil War', International Studies Quarterly (Vol. 63, No. 4, 2019), pp. 692-706; Marina G Petrova, 'What Matters is Who Supports you: Diaspora and Foreign States as External Supporters and Militants' Adoption of Nonviolence', Journal of Conflict Resolution (Vol. 63, No. 9, 2019), pp. 2155-79; Mark Toukan, 'International Politics by Other Means: External Sources of Civil War', Journal of Peace Research (Vol. 55, No. 6, 2019), pp. 812-26; Ryan Grauer and Dominic Tierney, 'The Arsenal of Insurrection: Explaining Rising Support for Rebels', Security Studies (Vol. 27, No. 2, 2018), pp. $263-$ 95; Lise Morjé Howard and Alexandra Stark 'How Civil Wars End: The International System, Norms, and the Role of External Actors', International Security(Vol. 42, No. 3, 2017/2018), pp. pp. 127-171; Niklas Karlén, 'The Legacy of Foreign Patrons: External State Support and Conflict Recurrence', Journal of Peace Research (Vol. 54, No. 4. 2017), pp. 499-512; Belgin San-Akca, States in Disguise: Causes of State Support for Rebel Groups (Oxford: Oxford University Press, 2016); Idean Salehyan, 'The Delegation of War to Rebels', Journal of Conflict Resolution (Vol. 54, No. 3, 2010), pp. 493515. 
contemporary civil wars into complex proxy wars in strategic settings ranging from South-East Ukraine ${ }^{6}$ and central Africa ${ }^{7}$ to the porous borders of Syria ${ }^{8}$ and Yemen. ${ }^{9}$

In 2013, the RUSI Journal published Andrew Mumford's discussion on the role of proxy warfare in shaping future conflict ${ }^{10}$ as a preamble to his wider analysis of the phenomenon. ${ }^{11}$ Taken together, Mumford's work revived a debate long ignored by strategic and security studies. Fast forward six years and the future of proxy wars has become their present focus. For example, seven entries into the International Crisis Group's '10 Conflicts to Watch in 2020' are currently being shaped by proxy

\footnotetext{
${ }^{6}$ Andrew S Bowen, 'Coercive Diplomacy and the Donbas: Explaining Russian Strategy in Eastern Ukraine', Journal of Strategic Studies (Vol. 42, No. 3-4, 2019), pp. 312-43; Vladimir Rauta, 'Proxy Agents, Auxiliary Forces, and Sovereign Defection: Assessing the Outcomes of Using Non-State Actors in Civil Conflicts', Southeast European and Black Sea Studies (Vol. 16, No. 1, 2016), pp. 91111.

${ }^{7}$ Henning Tamm, 'Status Competition in Africa: Explaining the Rwandan-Ugandan Clashes in the Democratic Republic of Congo', African Affairs (Vol. 118, No. 472, 2019), pp. 509-30; Noel Twagiramungu et al., 'Re-Describing Transnational Conflict in Africa', Journal of Modern African Studies (Vol. 57, No. 3, 2019), pp. 377-91; Quint Hoekstra, 'The Effect of Foreign State Support to UNITA During the Angolan War (1975-1991)', Small Wars and Insurgencies (Vol. 29, No. 5-6, 2018), pp. 981-1005.

${ }^{8}$ Keith A Grant and Bernd Kaussler, 'The Battle of Aleppo: External Patrons and The Victimization of Civilians in Civil War', Small Wars and Insurgencies (Vol. 31, No. 1, 2020), pp. 1-33; Haian Dukhan, State and Tribes in Syria: Informal Alliances and Conflict Patterns (New York, NY and Abingdon: Routledge, 2019); Christopher Phillips, The Battle for Syria: International Rivalry in The New Middle East (New Haven, CT and London: Yale University Press, 2016).

9 Jack Watling, 'Iran's Objectives and Capabilities: Deterrence and Subversion', RUSI Occasional Papers (February 2019).

${ }^{10}$ Andrew Mumford, 'Proxy Warfare and the Future of Conflict', RUSI Journal (Vol. 158, No. 2, 2013), pp. 40-46.

${ }^{11}$ Mumford, Proxy Warfare.
} 
dimensions: Afghanistan, Burkina Faso, Libya, Kashmir, Syria, Ukraine, and Yemen. Take for example Libya, now a veritable microcosms of proxy intervention:

\begin{abstract}
As a result, the conflict's protagonists are no longer merely armed groups in Tripoli fending off an assault by a wayward military commander. Instead, Emirati drones and airplanes, hundreds of Russian private military contractors, and African soldiers recruited into Haftar's forces confront Turkish drones and military vehicles, raising the spectre of an escalating proxy battle on the Mediterranean. ${ }^{12}$
\end{abstract}

Moreover, a recent paper by Jack Watling also included proxy warfare as one of its contemporary schools of thought. ${ }^{13}$ This article develops Mumford's analysis of the changing dynamics of proxy wars and argues for a relocation of proxy wars on a strategic footing by conceptualising them as strategic bargains waged on more complex grounds than risk avoidance, cost efficiency and deniability.

First, the article briefly explores the issue of defining proxy wars. Second, it argues that the thinking about proxy wars should differentiate between strategic advantages and strategic goals. To this end, there is a brief survey of the contemporary reach of proxy wars with the aim of capturing the variation in reasons for waging proxy wars. The article then identifies two types of strategic goals sought through the employment of proxies: coercing and coping with an adversary. The

\footnotetext{
${ }^{12}$ Robert Malley, '10 Conflicts to Watch in 2020', Foreign Policy, 26 December 2019.

${ }^{13}$ Jack Watling, 'Proxy Warfare: Iran', in Peter Roberts (ed.), 'The Future Conflict Operating Environment Out to 2030', RUSI Occasional Papers (June 2019), pp. 11-18.
} 
differences between the two are delineated by contrasting the rationale behind the US decision to support Syrian rebels against President Bashar al-Assad with the Iranian strategy of proxy war in Syria. The article concludes by showing how a more nuanced grasp of explanations of proxy wars helps with their rapid integration into the broader spectrum of contemporary violence from great power competition to cyber and hybrid warfare.

\section{[h1]Preliminary Clarifications of the Concept}

In 2018, David Ucko and Thomas Marks argued that the US and the West 'are conceptually under-equipped to grasp, let alone counter, violent political challenges'. ${ }^{14}$ Except for the notions of 'asymmetric warfare' and 'hybrid war/warfare', ${ }^{15}$ the concept of 'proxy war' is best exemplified Ucko and Marks' stern warning. For a long time, the literature has claimed that proxy wars are underconceptualised and under-theorised, ${ }^{16}$ or, perhaps even more poignantly, rejected the concept outright and replaced it with conceptual alternatives. ${ }^{17}$ This context allowed Mumford to open the debate, partly in this journal, and to define proxy wars as 'the indirect engagement in a conflict by third parties wishing to influence its

\footnotetext{
${ }^{14}$ David H Ucko and Thomas A Marks, 'Violence in Context: Mapping the Strategies and Operational Art of Irregular Warfare', Contemporary Security Policy (Vol. 39, No. 2, 2018), pp. 206-33.

${ }^{15}$ Vladimir Rauta, 'Towards a Typology of Non-State Actors in "Hybrid Warfare": Proxy, Auxiliary, Surrogate, and Affiliated Forces', Cambridge Review of International Affairs (Online First, 2019).

${ }^{16}$ Bowen 'Coercive Diplomacy and the Donbas'; Candace Rondeaux and David Sterman, 'TwentyFirst Century Proxy Warfare', New America, February 2019.

${ }^{17}$ San-Akca, States in Disguise.
} 
strategic outcome'. ${ }^{18}$ With a rapid expansion in the literature over the last decade, there is now a much clearer understanding of the concept of proxy warfare and strong evidence that it has gained significant policy traction.

Brendan Sozer speaks of proxy warfare 'as an external actor(s) seeking to indirectly influence the outcome of a conflict in pursuit of their strategic policy objectives by providing direct and intentional assistance to an existing actor in the conflict'. ${ }^{19}$ This is similar to Tyron Groh's assessment that proxy wars involve 'directing the use of force by a politically motivated, local actor to indirectly influence political affairs in the target state'. ${ }^{20}$ Finally, I provided elsewhere a more expansive definition accodingaccording to which a proxy war is 'a violent armed interaction resulting from the polarization of competing political goals between two organised parties, a Beneficiary and a Target, in which at least one party engages the other indirectly in sustained collective violence through a third party, the Proxy'. ${ }^{21}$ Whilst there is still some debate over concepts, ${ }^{22}$ scholars agree on a set of core features of proxy war: the role of the third party; indirect intervention; and an essentially relational interaction between actors. The literature thus addressed David Sterman's

\footnotetext{
${ }^{18}$ Mumford, Proxy Warfare, p. 1.

${ }^{19}$ Brendan Sozer, 'Development of Proxy Relationships: A Case Study of the Lebanese Civil War', Small Wars and Insurgencies (Vol. 27, No. 4, 2016), p. 643.

${ }^{20}$ Groh, Proxy War, p. 29.

${ }^{21}$ Rauta, 'A Structural-Relational Analysis of Party Dynamics in Proxy Wars', p. 457.

${ }^{22}$ Sozer, 'Development of Proxy Relationships', p. 643; Vladimir Rauta et al., 'A Symposium Debating "Surrogate Warfare" and the Transformation of War', Defence Studies (Vol. 19, No. 4, 2019), p. 8.
} 
suggestion that the definition of a proxy war needs to be focused on 'the constitutional status of the agents and actors involved in a conflict, rather than purely on the degree to which an external power is involved'. ${ }^{23}$ With more dynamic conceptualisations, the debate has slowly moved on from seeing 'proxy war' as 'a dirty word in foreign affairs', ${ }^{24}$ and this article draws on this by developing a strategic understanding of its appeal and logic.

\section{[h1]Towards a Strategic Understanding of Proxy Wars}

[h2]The Policy Appeal of Proxy Wars: Strategic Advantages and Strategic Goals References to contemporary proxy wars demonstrate the significant challenge they pose to the international security environment. ${ }^{25}$ As Geraint Hughes aptly puts it, proxy wars offer 'a superficially seductive policy option to any state that is (to quote Alexander Pope) "[willing] to wound, and yet afraid to strike"'.26 It is no surprise then that proxy wars extend beyond the violence of the Syrian, Iraqi or Yemeni civil wars. In 2019, in a remarkable recognition of the threat of proxy wars to the international security environment, the Nobel Peace Prize was awarded to the Ethiopian Prime Minister Abiy Ahmed Ali for his efforts to resolve the border conflict with

\footnotetext{
${ }^{23}$ David Sterman, 'How Do We Move Beyond “Proxy” Paralysis?', New America, 7 March 2019.

${ }^{24}$ Sozer, 'Development of Proxy Relationships', p. 643.

${ }^{25}$ Rauta and Mumford, 'Proxy Wars and the Contemporary Security Environment'.

${ }^{26}$ Geraint Alun Hughes, 'Syria and the Perils of Proxy Warfare', Small Wars and Insurgencies (Vol. 25, No. 3, 2014), p. 523.
} 
neighbouring Eritrea ${ }^{27}$. Their 1998-2000 inter-state war, resulting in catastrophic fatalities on both sides and ending in a military stalemate, had taken the shape of low-intensity proxy wars for almost two decades and engulfed most of the Horn of Africa.

In its sixth year now, the violence in South-East Ukraine exposes other facets of the strategic use of proxies. The escalation of protests in Kiev in November 2013 was followed first by the March 2014 annexation of the Crimea Peninsula by the Russian Federation, and second by a separatist civil war. Ukraine presents a clear case of complementary direct and indirect military interventions which has attracted fervent scholarly dialogue. ${ }^{28}$ On the one hand, the annexation of Crimea was a case of covert direct military intervention carried out by Russian Special Forces with the help of local auxiliaries. On the other, the violence in the south-east became a proxy war orchestrated and managed by Russia for the exact purposes of wounding the authorities in the Ukrainian capital, Kyiv.

This combination of pathways for a broader set of strategic goals speaks directly to the assertion of former Commander of the UK's Joint Forces Command, General Richard Barrons that 'proxy warfare is the most successful kind of political war being waged of our generation'. ${ }^{29}$ This section argues that what makes proxy

\footnotetext{
${ }^{27}$ BBC, 'Nobel Peace Prize: Ethiopia PM Abiy Ahmed Wins', 11 October 2019.

${ }^{28}$ Lawrence Freedman, Ukraine and the Art of Strategy (Oxford: Oxford University Press, 2019); Bowen 'Coercive Diplomacy and the Donbas'; Rauta, 'Proxy Agents, Auxiliary Forces, and Sovereign Defection'.

${ }^{29}$ Roberts, 'The Future Conflict Operating Environment Out to 2030', p. 11.
} 
wars successful is their ability to help meet the demands of a range of strategic goals and not merely ease or facilitate the waging of international war. A wider remit of purposes was drawn by Daniel Byman and colleagues early in the debate and repeated in the literature in various degrees of detail, including: irredentism; prestige; regime change; plunder; strengthening internal security; and supporting coreligionists and co-ethnics. ${ }^{30}$ For example, the strategy of retaliation through proxy that characterised Ethiopian-Eritrean relations for the last 20 years is similar in practice but different in strategic logic to Russia's strategy of supporting so-called 'separatists' against Ukraine. Both are also distinct in strategic makeup to Iran's employment of an infrastructure of proxies in the Middle East. The US delegating war to Kurdish factions to fight Daesh (also known as the Islamic State of Iraq and Syria, ISIS) in Syria accompanied by US airpower support ${ }^{31}$ was informed by different considerations from the Cold War calculus leading President Richard Nixon's administration in 1972 to arm Kurdish groups to fight the Iraqi regime, following pressure from the Shah of Iran. ${ }^{32}$

In order to prevent or prevail in fighting proxy wars, a strategic understanding of why proxy wars are waged is needed. This article proposes differentiating between

\footnotetext{
${ }^{30}$ Daniel Byman et al., Trends in Outside Support for Insurgent Movements (Santa Barbara, CA: RAND, 2005).

${ }^{31}$ Ben Hubbard et al., 'Abandoned by U.S. in Syria, Kurds Find New Ally in American Foe', New York Times, 13 October 2019.

${ }^{32}$ Asaf Siniver, Nixon, Kissinger, and US Foreign Policy Making (Cambridge: Cambridge University Press, 2008).
} 
the advantages and goals of waging proxy wars. Since Mumford opened the debate, proxy wars have been measured against their ability to offer an easy solution to complex problems and 'to hit the political sweet spot'. ${ }^{33}$ In Byman's view, proxies 'enable intervention on the cheap. They cost a fraction of the expense of deploying a state's own forces and the proxy does the dying. Because the costs are lower, proxy war is also more politically palatable'. ${ }^{34}$ And next to cost-effectiveness are deniability, ${ }^{35}$ risk aversion and shock absorption.

Yet, what actors want to achieve by choosing a proxy (in other words their range of goals) is not sufficiently integrated in current examinations of the problem. Next this article presents proxy wars as strategic bargains and outlines two goalfocused strategies of waging proxy wars: coping and coercing. These are explored by comparing the US decision to support Syrian rebels against al-Assad's regime with the Iranian strategy of proxy war in Syria in support of the same regime.

\section{[h2]Proxy Wars as Strategic Bargains: Coping and Coercing}

The literature usually describes proxy wars as a two-step process: the delegator of war (the Beneficiary) decides on the allocation of resources and the Proxy decides on the distribution of said resources against the target adversary. It is often mentioned that the process of decision-making involves conditionality concerning issues of

\footnotetext{
${ }^{33}$ Daniel Byman, 'Why States are Turning to Proxy Wars', National Interest, 26 October 2018.

${ }^{34}$ Byman, 'Why States are Turning to Proxy Wars'.

${ }^{35}$ Rory Cormac and Richard J. Aldrich, 'Grey is the New Black: Covert Action and Implausible Deniability', International Affairs (Vol. 94, No, 3, 2018), pp. 477-94.
} 
control, management of the relationship, and the delivery of strategic outputs ${ }^{36}$. To this end, explanations have centred on supply-demand models, goal-preference dynamics, or selection mechanisms, with each presenting different accounts of how the parties give and take and decide over the responsibility over and the conduct of war. ${ }^{37}$ Yet, what the Beneficiary wants to achieve in terms of its strategic goals regarding the target is insufficiently discussed in a theoretically meaningful way. To address this, this article reconceptualises proxy wars as: a strategic enterprise involving at least two parties negotiating over the delegation, management and pursuit of indirect war against a target adversary.

Proxy wars are strategic bargains requiring dynamic and purposeful interaction, and entailing a range of trade-offs: between available proxies; between what one party wants to achieve and what it does achieve; between competing agendas and competing targets; between the ambition of control over the proxy and the practical implementation of control; and between diverging trajectories strategic goals may take once war is underway. ${ }^{38}$ This is essentially a bargaining situation 'in which the ability of one participant to gain his ends is dependent to an important

\footnotetext{
${ }^{36}$ Salehyan, 'The Delegation of War to Rebels'.

${ }^{37}$ Rauta, 'A Structural-Relational Analysis of Party Dynamics in Proxy Wars'; San-Akca, States in Disguise; Idean Salehyan, Kristian Skrede Gleditsch and David E Cunningham, 'Explaining External Support for Insurgent Groups', International Organization (Vol. 65, No. 4, 2011), pp. 709-744.

${ }^{38}$ Navin A Bapat, 'Understanding State Sponsorship of Militant Groups', British Journal of Political Science (Vol. 42, No. 1, 2012), pp. 1-29.
} 
degree on the choices or decisions that the other participant will make', ${ }^{39}$ with the difference that the chain of participants is no longer dyadic, but triadic.

More importantly, in delegating to the Proxy, the Beneficiary essentially decides on its target-related aims. Here the article draws the following distinction between goals: it proposes that goals are understood as a binary of strategic coercion and coping with an adversary. The distinction is grounded in Rupert Smith's observation, according to which,

'the main difference between confrontations and conflicts [is] their purpose. In confrontations the aim is to influence the opponent, to change or form an intention, to establish a condition and, above all, to win the clash of wills. In conflicts the purpose is to destroy, take, hold; to forcibly attain a decisive outcome by the direct application of military force' ${ }^{40}$

This distinction allows the understanding of coercion as a compliance-seeking endeavour which, as C R Mitchell argued, forces the opponent to 'abandon its goals by imposing unacceptable costs on goal-seeking behaviour ${ }^{\prime}{ }^{41}$ and coping as a

\footnotetext{
${ }^{39}$ Thomas C Schelling, 'The Retarded Science of International Strategy', Midwest Journal of Political Science (Vol. 4, No. 2, 1960) pp. 110.

${ }^{40}$ Rupert Smith, The Utility of Force: The Art of War in the Modern War (London: Penguin Books, 2006), p. 182.

${ }^{41}$ C R Mitchell, The Structure of Conflict (London: Palgrave Macmillan, 1981), p. 122.
} 
mechanism of waging and yielding of violence outside a submission-seeking intent and more as a tool of managing an adversary.

By distinguishing between these two strategies of proxy war, this article highlights a missing layer in the explanations: that proxy wars are waged for both maximalist, coercive goals as well as for discrete, conservative goals such as the management of (parts of) complex issues. It draws attention to the strategic variation of wars by proxy indirect war and to the essentially iterative character of the bargaining: the parties do not negotiate only once, but repeatedly following the pace of the war itself. Specifically, this is not a one-time grant of war responsibility, but a series of strategic decisions: first, concerning the aims of the war (and the target); second, the choice of proxy; third, the balancing between the Beneficiary and proxy agendas.

\section{[h2]One War, Two Strategies}

In this sub-section, the differences between the two strategies of coercion and coping are briefly sketched by comparing former US President Barack Obama's decision to support Syrian rebels against al-Assad's regime with the Iranian strategy of proxy war in Syria in support of the same regime. The two cases speak to the strategic logics of coping and coercing as ideal types and, as such, significant case complexity is sacrificed, allowing, however, future refinements of the argument. The empirical background for this short comparison is offered by the Syrian civil war, whose evolution from the Arab uprising to multiparty internationalised war needs 
not be re-litigated here, as it has been discussed in the pages of this journal ${ }^{42}$ and elsewhere. ${ }^{43}$ The Syrian civil war is relevant for this article's discussion given that it has become the contemporary archetype of wars by proxy. ${ }^{44}$

Obama's vacillation over the decision to support or not support Syrian rebels underlines the utility of proxy wars as strategic coping mechanisms, and recently published Obama-era memoirs from staffers and cabinet members ${ }^{45}$ confirm this. The first proposal to support Syrian rebels was made in autumn 2012, and Ben Rhodes, then Deputy National Security Adviser for Strategic Communications, characterised it as a 'small-scale recommendation to engage a portion of the opposition, providing them with a fraction of the support that Russia and Iran were providing to the Assad regime'. ${ }^{46}$ Then CIA Director, David Petraeus, advanced the plan, receiving support from then Secretary of State, Hillary Clinton, who placed the Syrian conflict in the context of a wider regional proxy war and emphasised the role

\footnotetext{
${ }^{42}$ Susan Schulman, 'From Homs to Aleppo: A Journey Through the Destruction of the Syrian War', RUSI Journal (Vol. 162, No. 6, 2017), pp. 44-59; Susan Schulman, 'From Homs to Aleppo: A Journey Through the Destruction of the Syrian War', RUSI Journal (Vol. 163, No. 1, 2018), pp. 6281.

${ }^{43}$ Dukhan, State and Tribes in Syria; Tom Smith et al., 'Understanding the Syria Babel: Moral Perspectives on the Syrian Conflict from Just War to Jihad', Studies in Conflict \& Terrorism, 3 December 2018, <https://doi.org/10.1080/1057610X.2018.1523358>, accessed 11 December 2019. ${ }^{44}$ Olivia Giles, 'How did the Syrian Civil War Become a Proxy War?', National Interest, 13 September 2019.

${ }^{45}$ Peter Beinar, 'Obama's Idealists: American Power in Theory and Practice', Foreign Affairs, November/December 2019.

${ }^{46}$ Ben Rhodes, The World as It Is: Inside the Obama White House (London: Penguin Random House 2018), p. 198.
} 
of Hizbullah as Iran's proxy in Lebanon and Syria. ${ }^{47}$ Both Clinton and Petraeus presented the proxy option first and foremost as a strategy of managing the situation. Ben Rhodes explains: '[Petraeus] was also honest about what it was and wasn't: This won't change the direction of the war, he'd say; it will allow us to build relationships with the opposition' ${ }^{48}$ In her memoirs, Clinton was adamant that 'the idea was to give us a partner on the ground we could work with that could do enough to convince Assad and his backers that a military victory was impossible' ${ }^{49}$ Similarly, National Security Adviser, Susan Rice, argued that the rebels could only have increased military pressure yet at no point significantly threatened the regime. In fact, Rice defended retrospectively Obama's decision questioning 'the wisdom or arming and training the Syrian rebels' given it would have merely created a temporary stalemate..$^{50}$

Leon Panetta, then US Secretary of Defense, and James Clapper, then Director of National Intelligence, argued that any shifts in the goals of the proxy policy were impeded by the twin problems of Assad's military strength and Russian support, as well as the rebels' lack of organisation and ties to terrorist groups. ${ }^{51}$ Susan Rice

\footnotetext{
${ }^{47}$ Hillary Rodham Clinton, Hard Choices (London: Simon \& Schuster, 2014), p 349.

${ }^{48}$ Rhodes, The World as It Is, p. 198. Emphasis in original.

${ }^{49}$ Clinton, Hard Choices, p. 392.

${ }^{50}$ Susan Rice, Tough Love. My Story of the Things Worth Fighting For (New York, NY, London: Simon \& Schuster, 2019), p. 368.

${ }^{51}$ Leon Panetta, Worthy Fights: A Memoir of Leadership in War and Peace (New York, NY: Penguin Press, 2014); James R Clapper, Facts and Fears: Hard Truths from a Life in Intelligence (New York, NY: Viking, 2018), p. 168.
} 
emphasised the particular difficulty of 'how to help the good guys, and those in the gray area, without inadvertently providing sophisticated weapons and training to terrorists. ${ }^{52}$ Initially, Obama rejected the proxy proposal, and United States Deputy Secretary of State, William Burns, recounts that the weight of the US's history of proxy wars outweighed the confidence of the intelligence agencies to quickly and effectively arm and train Syrian rebels. ${ }^{53}$ Obama reversed course after al-Assad's use of chemical weapons by joining Sunni Arab and Turkish US partners in arming and training Syrian rebels, an effort that expanded once countering Daesh gained strategic priority.

Limited and conservative in terms of what they wanted to achieve, the $\mathrm{CIA}$ covertly armed and trained rebels in the Free Syrian Army, and the Pentagon later set up and began arming the Syrian Democratic Forces, ${ }^{54}$ and their failures have been discussed at length chiefly of which the repeated clashes between CIA and Pentagon sponsored rebel groups ${ }^{55}$. Yet in trying to manage a strategically unmanageable situation, this proxy policy of coping with an entrenched crisis was, in Burns' words, 'never about victory on the battlefield. ${ }^{56}$ Rather,

\footnotetext{
${ }^{52}$ Rice, Tough Love, p. 367.

${ }^{53}$ William J Burns, The Back Channel. A Memoir of American Diplomacy and the Case for Its Renewal (New York, NY: Random House, 2019), p. 328.

${ }^{54}$ Ronan Farrow, War on Peace. The End of Diplomacy and the Decline of American Influence (London: William Collins, 2018), p. 156.

${ }^{55}$ Nabih Bulos, W J Hennigan and Brian Bennet, 'In Syria, Militias Armed by the Pentagon Fight Those Armed by the CIA', LA Times, 27 March 2016.

${ }^{56}$ Burns, The Back Channel, p. 327
} 
'It was about trying to demonstrate to Assad and his outside backers that he couldn't win militarily, and that his political options were going to narrow the longer the fighting continued. It was a way to manage the opposition, and to use our provision of training and equipment to help make them a more coherent and responsive force. ... I hated the then-fashionable term "skin in the game", which always seemed too glib in the face of Syria's ugly realities, but that was essentially what this was about ${ }^{\prime 57}$

To understand proxy wars seeking maximalist coercive goals, the article now turns to Iran's proxy strategy in Syria. From the start, however, this must be couched in Iran's broader approach to the Middle East involving a network of proxies meeting a range of strategic goals: from placating Israel, to countering its rival Saudi Arabia, to reducing US presence in Iraq, to fighting Daesh, and to effectively building a land corridor from Teheran to Damascus. ${ }^{58}$ As mentioned, Iran has sponsored the Houthi rebels to build 'a proxy force designed to pressure the SLC [Saudi-led coalition] and expand Iranian regional influence'.$^{59}$ Next to the Houthis, whose rise to prominence followed 2014, Iran has long cultivated a vast proxy network operating across the

\footnotetext{
${ }^{57}$ Burns, The Back Channel, p. 327.

${ }^{58}$ Afshon Ostovar, 'Iran, Its Clients, and the Future of the Middle East: The Limits of Religion', International Affairs (Vol. 94, No. 6, 2018), pp. 1237-55.

${ }^{59}$ Votel, 'Great Power Competition'.
} 
Middle East with both successes and failures. ${ }^{60}$ Known as the 'Axis of Resistance' 61 , Iran's proxy network covers Iraq, Afghanistan, Syria, Lebanon and Yemen, organised under the aegis of Islamic Revolutionary Guards Corps (IRGC) elite Quds Force ${ }^{62}$. In spite of being part of the fabric of the Shia Crescent, these proxies have retained enormous strategic independence, operating in individual strategic contexts resulting in differentiated proxy relationships with Teheran. Hizbollah, for example, has long outgrown its proxy status, currently ranking as Iran's oldest, most sophisticated, and best-armed ally. ${ }^{63}$ In Iraq, the network includes the Badr Organization, a political party which began as a covert organisation against Iraq President Saddam Hussein's regime, now Iran's most powerful Shiite proxy in the country ${ }^{64}$. Iran's reach into Iraq has been facilitated by paramilitary groups such as Kata'ib Hezbollah, Asa'ib Ahl alHaq, and Saraya al-Salam (Peace Companies) ${ }^{65}$ These militias came to dominate the Popular Mobilisation Forces, the 100,000-member volunteer force set up following

\footnotetext{
${ }^{60}$ Ostovar, 'Iran, its Clients, and the Future of the Middle East'.

${ }^{61}$ Robin Wright, 'Iran Entrenches Its “Axis of Resistance” Across the Middle East', The New Yorker, 19 September 2019.

${ }^{62}$ Afshon Ostovar, Vanguard of the Imam. Religion, Politics, and Iran's Revolutionary Guards (Oxford: Oxford University Press).

${ }^{63}$ Wright, 'Iran Entrenches Its "Axis of Resistance” Across the Middle East'; Amal Saad, 'Challenging the Sponsor-Proxy Model: the Iran-Hizbullah Relationship', Global Discourse: An Interdisciplinary Journal of Current Affairs (Vol. 9, No. 4, 2019), pp. 627-650.

${ }^{64}$ Babak Dehghanpisheh, 'Special Report: The fighters of Iraq Who Answer to Iran', Reuters, 12 November 2014.

${ }^{65}$ Omer Carmi, 'Deconstructing and Countering Iran's Threat Network', Washington Institute for Near East Policy, Policy Note 42, 2017.
} 
the rise of Daesh also known as Hashb al-Shabi, and brought significant changes to the calculus of Iraqi security ${ }_{-6}^{66}$

Since 2012, the IRGC has adapted the proxy patent, developed with Hizbullah and Shia militias across Syria. As Andreas Krieg and Jean-Mark Rickli noted recently, this is part and parcel of Iran's mosaic defence in which decentralisation of command and delegation of warfighting are twinned with a high degree of strategic patience. ${ }^{67}$ Established Iraqi militias such as the Badr Organization, Kata'ib Hezbollah, Asa'ib Ahlal-Haq, and Harakat Hezbollah al-Nujaba organised, trained and supervised a pack of proxies whose role has been key to the Iranian support of al-Assad's regime ${ }^{68}$. Following the proposed strategic logic, it could be argued that Iran has employed an essentially coercive logic of wars by proxy. First, Shia proxy militias played a critical role in defeating Syrian rebel groups and fighting Daesh. This was the case of the Liwa Fatemiyoun active in Syria from the early days of the conflict. Others, not only helped repel the rebels but were also key to ensuring control over strategically relevant town such as Qusair, Homs, Aleppo and Damascus. ${ }^{69}$ They did not simply

\footnotetext{
${ }^{66}$ Colin Clarke and Phillip Smyth, 'The Implications of Iran's Expanding Shi'a Foreign Fighters Network', CTCSentinel (Vol. 10, No. 10, 2017), pp. 14-18.

${ }^{67}$ Andreas Krieg and Jean-Mark Rickli, Surrogate Warfare: The Transformation of War in the Twenty-First Century (Washington, DC: Georgetown University Press, 2019), pp. 173-74.

${ }^{68}$ Phillips, The Battle for Syria.

${ }^{69}$ The Economist, 'The Future of Syria: Smaller, in Ruins and more Sectarian', 30 June 2018.
} 
seek to defeat the rebels' military, but to replace their authority entirely by erecting parallel security governance structures. ${ }^{70}$

In stark contrast with the US effort to manage and cope with the wider problem of the Syrian civil war, Ranj Alaaldin explains that Iran's proxy effort is decidedly oriented towards transforming 'its proxies in Syria into fully entrenched components of whatever political system emerges from the ruins of conflict'. ${ }^{71}$ Second, and more importantly, Iran's proxy war effort is oriented towards securing strategic control over a land corridor linking Tehran to Beirut through Iraq and Syria. The political symbolism and strategic implications of this gambit's potential success is manifold, involving Lebanon, Israel and Iraq. ${ }^{72}$ The expansion of Hizbullah's role beyond Lebanon afforded by the Syrian civil war helps locate Iran's multi-front wars, ${ }^{73}$ but, more importantly, it speaks to Iran's pan-Shia focus and how the changes brought to the Iranian way of war will not be confined to Syria. ${ }^{74}$

Distinguishing between the two logics highlights their similarities and differences. As Brian Katz recently argued, 'the Iranian approach to proxy warfare and how they cultivate binding partnerships with local actors offers lessons the United

\footnotetext{
${ }^{70}$ Ranj Alaaldin, 'How Iran used the Hezbollah Model for Domination', New York Times, 30 March 2018.

${ }^{71}$ Alaaldin, 'How Iran used the Hezbollah Model for Domination'.

${ }^{72}$ The Economist, 'Syria's multi-sided war escalates yet again', 22 June 2017.

${ }^{73}$ Magnus Ranstorp, 'Hezbollah's Calculus After the Iran Nuclear Deal', CTC Sentinel (Vol. 9, No. 1, 2016), pp. 10-13.

${ }^{74}$ Ariane M Tabatabai, 'Syria Changed the Iranian Way of War', Foreign Affairs, 16 August 2019.
} 
States can learn from'.$^{75}$ The two proxy war types presented in this article can help with the wider lesson-learning effort, especially as future intelligence assessments of the Middle East, according to the US Office of the Director of National Intelligence, are characterised by '[p]olitical turmoil, economic fragility, and civil and proxy wars'. ${ }^{76}$ For policymakers this has significant implications as it can help distinguish between the positive and negative consequences of using third parties. Specifically, a differentiated and strategic understanding would help explain worst case scenarios in which conventional state-to-state is matched or driven by proxy fighting either intheatre or elsewhere. As General Kenneth F McKenzie, Jr took over command of US Central Command in March 2019, The Guardian reported that Iran's most prominent military leader, Qasem Soleimani, leader of the Quds Force, issued an instruction to Iraqi militias 'to prepare for proxy war', ${ }^{77}$ attacked tankers in the Gulf of Oman, ${ }^{78}$ and had the IRGC use a surface-to-air missile to down a US MQ-4 Triton drone near the

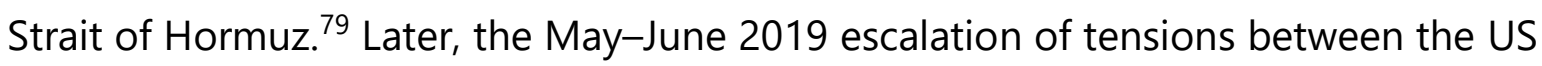
and Iran raised the prospects of how Iran's 'threat network' might be employed. ${ }^{80}$ As Peter Beinart observed, however, other than calls from foreign policy hawks for war

\footnotetext{
${ }^{75}$ Brian Katz, 'What the U.S. Can Learn from Iranian Warfare', The Atlantic, 19 October 2019.

${ }^{76}$ Daniel R Coats, 'Statement for the Record: Worldwide Threat Assessment of the US Intelligence Community', Office of the Director of National Intelligence, 29 January 2019, p. 29.

${ }^{77}$ Martin Chulov, 'Iran Tells Middle East Militias: Prepare for Proxy War', The Guardian, 16 May 2019.

${ }^{78}$ David D Kirkpatrick, Richard Pérez-Peña and Stanley Reed, 'Tankers Are Attacked in Mideast, and U.S. Says Video Shows Iran Was Involved', New York Times, 13 June 2019.

${ }^{79}$ BBC, ‘Strait of Hormuz: US Confirms Drone Shot Down by Iran', 20 June 2019.

${ }^{80}$ Carmi, 'Deconstructing and Countering Iran's Threat Network'.
} 
with Iran and qualifications of future consequences as 'undesirable', considerations of Iranian responses were largely mute. ${ }^{81} \mathrm{~A}$ war with Iran has the potential to include Iraq, as well as Afghanistan, Lebanon, Syria, and Yemen, ${ }^{82}$ largely in its proxy war dimensions, whose implications should not be neglected. As the Trump administration approved the strike that killed Qasem Soleimani in early January 2020, the reality of a multi-front proxy war with Iran made the object of speculation about Iran's response ${ }^{83}$. The likelihood of the United States finding itself at war with Iranianbacked militias is high given the combination of the proxies' ample space for strategic, independent action and the fact that Iran's investment into this proxy network served to meet the demands of one such crisis. With Iran recalibrating its response, the future of Iran's proxy network should not be dismissed for it extends beyond the proxies' gravitation toward Soleimani's rallying power ${ }^{84}$. Equally, and perhaps, more importantly, the reverse should not be the case either as power plays involving proxies have been a measure of Iran's weakness, contributing to 'Tehran's outcast status, decreasing the country's economic power and diplomatic clout'. ${ }^{85}$

\section{[h1]Conclusion: The Future of (the Study) of Proxy Wars}

\footnotetext{
${ }^{81}$ Peter Beinart, 'The Questions the Iran Hawks Haven't Answered', The Atlantic, 24 June 2019.

${ }^{82}$ Ilan Goldenberg, 'What a War with Iran Would Look Like', Foreign Affairs, 4 June 2019.

${ }^{83}$ Ilan Goldberg, 'Will Iran's Response to the Soleimani Strike Lead to War?', Foreign Affairs, 03 January 2020.

${ }^{84}$ Ali Soufan, 'Qassem Soleimani and Iran's Unique Regional Strategy', CTCSentinel (Vol. 11, No. 11, 2018), pp. 1-12.

${ }^{85}$ Daniel Byman, 'How Terrorism Helps - and hurts - Iran', The Washington Post, 03 January 2020.
} 
This article proposes a distinction between two ideal categories of goals behind proxy wars in the context of complex civil wars. It does so by drawing on Mumford's programmatic piece on the future of proxy wars. Since then, proxy wars have been interwoven in escalatory state-to-state dynamics, great power competition and cyber or hybrid warfare. Giving the keynote address at the RUSI Land Warfare Conference in April 2019, former Defence Secretary Penny Mordaunt pointed to the current strategic context as one in which the UK has to 'deal with the hybrid dangers as nations increasingly employ proxy actors to carry out aggression and intimidation at arms-length but now below the threshold of armed combat'. ${ }^{86}$ This serves, once more, to locate proxy wars as a widely spread security issue with an even wider empirical reach whose implications need to be given significant consideration.

The policymakers' emphasis on the proxy war dimension of contemporary war reveals a problem that has been not just long in the making but one that will shape political violence for the foreseeable future. This article aims to open this conversation on proxy wars and great power competition or cyber warfare by highlighting the need for strategic thinking to the essentially strategic employment of proxy wars. The future study of the present and future of proxy wars speaks to the emergence of an enduring research programme whose findings will shape strategic

\footnotetext{
${ }^{86}$ Ministry of Defence, 'Defence Secretary Keynote Speech at the Land Warfare Conference 2019', 4 June 2019, < https://www.gov.uk/government/speeches/defence-secretary-keynote-speech-at-theland-warfare-conference-2019>, accessed 11 December 2019.
} 
and policy thinking. As the world moves forward, this is essential since, as Daniel Byman put it, proxy warfare 'is not going away'. ${ }^{87}$

Vladimir Rauta is a Lecturer in Politics and International Relations at the University of Reading. He researches proxy wars and has published articles in International Relations, Studies in Conflict \& Terrorism, and the Cambridge Review of International Affairs. He is currently working on a book project analysing the contemporary dynamics of proxy wars. He would like to thank Dr Corinne Heaven for her useful comments on earlier drafts.

${ }^{87}$ Byman, 'Why States are Turning to Proxy Wars'. 